UDC: 342.727

342.727:[316.65:316.774-051(497.7-15)

DOI: $10.46763 /$ SCGW212499k

\title{
PERCEPTION OF FREEDOM OF EXPRESSION OF MEDIA WORKERS IN THE WESTERN REGION OF THE REPUBLIC OF NORTH MACEDONIA
}

\author{
Iskra Koroveshovsкa \\ Assistant professor, PhD Faculty of Law, University "GoceDelcev"-Shtip \\ e-mail: iskra.koroveshovska@ugd.edu.mk \\ Jordanka Galeva \\ Assistant professor, PhD, Faculty of law, Faculty of Law, \\ University “GoceDelcev"-Shtip \\ e-mail: jordanka.galeva@ugd.edu.mk \\ Andon Majhoshev \\ Associate professor, PhD, Faculty of Law, University “GoceDelcev"-Shtip \\ e-mail: andon.majhosev@ugd.edu.mk \\ Jadranka Denkova \\ Associate professor, PhD, Faculty of Law, University “GoceDelcev”-Shtip \\ e-mail: jadranka.denkova@ugd.edu.mk
}

\begin{abstract}
The right to freedom of expression is one of the fundamental human rights guaranteed by Article 16 of the Constitution in Republic of N. Macedonia and by several international documents as the Universal Declaration of Human Rights, the European Convention for the Protection of Human Rights, International Covenants (on civil and political rights and on economic, social and cultural rights) and other legal acts that have also been ratified in our country. Constitutional Article 16 guarantees freedom of speech, public information, free access to information, reception and transmission of information as well as free establishment of public information institutions. In order to obtain concrete results regarding the implementation of these rights, the paper analyzes the subject of media workers' perception of freedom of expression, the degree of censorship and self-censorship of media workers and the reasons that affect restriction of the right. The research included media workers from the media in the Western region of the Republic of N. Macedonia. The main guide research question is "What is the perception of media workers about the degree of freedom of expression in the Western planning region of the Republic of Macedonia?"
\end{abstract}

Keywords: media, freedom of expression, censorship, Republic of N. Macedonia 


\title{
ПЕРЦЕПЦИЈА НА СЛОБОДАТА НА ИЗРАЗУВАЊЕ НА МЕДИУМСКИТЕ РАБОТНИЦИ ВО ЗАПАДНИОТ РЕГИОН НА РЕПУБЛИКА С. МАКЕДОНИЈА
}

\author{
Искра Коровешовска \\ Доц., Д-р., Правен Факултет, Универзитет „Гоце Делчев,, - Штип \\ e-mail: iskra.koroveshovska@ugd.edu.mk \\ Јорданка Галева \\ Доц., Д-р., Правен Факултет, Универзитет „Гоце Делчев,, - Штип \\ e-mail:jordanka.galeva@ugd.edu.mk \\ Андон Мајхошев \\ Проф., Д-р., Правен Факултет, Универзитет „Гоце Делчев,, - Штип \\ e-mail:andon.majhosev@ugd.edu.mk \\ Јадранка Денкова \\ Проф., Д-р.,Правен Факултет, Универзитет „Гоце Делчев,, - Штип \\ e-mail:jadranka.denkova@ugd.edu.mk
}

\section{Апстракт}

Правото на слобода на изразување е едно од основните човекови права кој на граѓаните во Република С. Македонија е им е загарантирано преку уставниот член 16. На меѓународно ниво ова право е дел од Универзалната декларација за човекови права, Европската Конвенција за заштита на човекови права, Меѓународните пактови (за граѓански и политички права и за економски, социјални и културни права) и други правни акти кои воедно се ратификувани и во нашата држава. Уставниот член 16 ја гарантира слободата на говорот, јавното информирање, слободен пристап кон информации, примање и пренесување на информации како и слободно основање на институции за јавно информирање. Со цел да се добијат конкретни резултати во однос на импелементацијата на овие права, во трудот е направена анализа чиј предмет е токму перцепцијата на медиумските работници за слободата на изразување, за степенот на цензура и автоцензура на медиумските работници како и за причините кои влијаат врз ограничувањето на ова право. Истражувањето ги опфати медиумските работници од медиумите во Западниот регион на Република С. Македонија. Основно истражувачко прашање по кое се водеше истражувањето е «Каква е перцепцијата на медиумските работници за степенот на слободата на изразување во Западниот плански регион на Република С. Македонија?»

Клучни зборови: медиуми, слобода на изразување, цензура, Република С. Македонија 


\section{1. Дефинирање и правна заштита на слободата на изразување, цензура и автоцензура}

\section{1 Дефинирање на поимите}

Слободата на медиумите е либерална вредност која извира од филозофијата на слободата и еднаквоста на граѓаните и претставува израз на демократските стремежи на граѓаните за повисоки политички права и воспоставување на политичка контрола над политичката власт. Секако дека не постои апсолутна слобода на медиумите, како што нема ни апсолутно слободна човекова активност, што значи дека не постои ни апсолутна слобода на медиумите да пишуваат и објавуваат секакви информации. Од животната и историска пракса се покажа дека постојат ситуации кога во јавен интерес е да се ограничи принципот на максималното зборување на вистината заради одредени повисоки општествени интереси. Оттука филозофијата на слободата на медиумите е во тоа да се одреди и границата на таа слобода, односно да се воспостави рамнотежа меѓу слободата на медиумите и слободата на изразување. Една од историските искажани мисли која најдобро ја дефинира силата и моќта на слободата на медиумите е онаа на францускиот император Наполеон Бонапарта кој ке каже: „Четири непријателски весници можат да бидатпоопасни од стоилјадна војска,, , или „Кога би ги пуштил уздиде на печатот, не би се одржал на власт ни четири месеии,.. ${ }^{l}$

Слободата на медиумите понекогаш се нарекува "четврта гранка на власта или четврти сталеж “. Овој назив укажува на фактот дека медиумите се важен контролен механизам за остварување на демократијата и демократските процеси во една држава и дека поседуваат огромна општествена (политичка) моќ. Новинарите како четврти сталеж (четврта власт) со својот критички однос кон власта вршат контрола над работата на избраните и именуваните функционери, така што можат слободно да пишуваат за нивните постапки, грешки и да ја информираат јавноста ${ }^{2}$. Секако ова имплицира на тоа дека новинарите имаат посебна одговорност да известуваат вистинито за сите релевантни настани од јавен интерес ${ }^{3}$. Од новинарот не се очекува само да информира вистинито, туку и да знае да ја извлече суштината од настанот, а притоа да се направи прифатлива рамнотежа помеѓу правото на јавноста на реално информирање за настаните и другите општествени обврски и цели кои понекогаш можат да бидат во судир со желбата да се сочува неограничениот пристап до информациите. Денес нема држава која не го прокламира начелото на слобода напечатот (медиумите), но исто така нема држава која на некој

\footnotetext{
${ }^{1}$ Груевски, Т.(2007), Историја на новинарството. Правен факултет и НИП «Студентски збор», Скопје, 114.

${ }^{2}$ Zaket, D. (2007),Novinarskaetika - moralnaodgovornostumedijima, Sluzbenglasnik, pp. 180

${ }^{3}$ Ibid
} 
друг начин не ги држи уздите на печатот (медиумите). Затоа што дури и во најдемократските општества во светот, каде што новинарството ужива висок степен на слобода на изразување и известување, на постои апсолутна слобода на печатот, бидејќи некои информации се однесуваат на осетливи воени, државни и економски тајни или на детска порнографија ${ }^{4}$. Единствено решение за овој проблем секако е да се допушти слобода на медиумите, а да се задржи можноста за цензура на информацијата за кои се мисли дека се опасни и штетни по безбедноста на државата (општеството) како целина.

Поимот цензура потекнува од латинскиот збор censura што значи претходно или дополнително оценување на печатени работи, кои по потреба можат да бидат забранети пред објавувањето или растурањето. Цензурата се спроведува од страна на државата или некоја друга организација и таа не се однесува само на печатот, туку и на други форми на научно и уметничко творештво и масовно комуницирање (театар, филм, радио, телевизија). Така

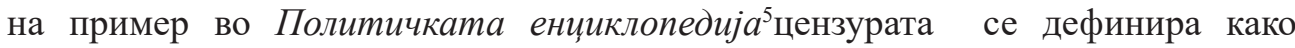
контрола од страна на органите на власта, црквата, политичките организации или приватните лица, на содржината на текстот, односно информацијата наменета за медиумите (штампата, радиото, ТВ, емисии, филмот, театарот, и сл.) пред нивното публикување или изведба. Во правниот речник таа се дефинира како ограничување на граѓанската слобода за изразување на мислата и претставува контрола на обвинувања или репресија на одредени содржини, идеи и изразувања, од страна на одредени органи кои имаат власт. Во одредени либерални држави, само во одредени случаи како на пример во воениот период била воведена превентивна цензура, додека во авторитарните држави таа се спроведува со цел да се спречат критики за дејствувањето на постоечките власти ${ }^{6}$. Во првиот случај причините се најчесто поврзани со безбедност на државата, вонредна состојба и сл. и во вакви ситуации известувањето од страна на новинарот е со двојна одговорност: кон јавноста која треба да биде благовремено и вистинито информирана и кон државата, во чиј случај новинарот треба да спречи изнесување на осетливи инфомрации и да умее да воспостави баланс во информирањето и безбедноста на државата. Во вториот случај, на авторитарните држави каде постои гушење на слободното откривање и ширење на информацијата, цензурата всушност е оној ограничувачки фактор на демократските тенденции во општеството. Во македонскиот случај според чл.16, став 7 од Уставот на РМ цензурата е забранета.

Во однос на автоцензурата, самиот термин упатува на самоцензурирање, односно кога новинарот/авторот на текстот свесно донесува одлука да не ја пренесе информацијата на јавноста. Ваквиот чин претставува свесно

${ }^{4}$ Ibid, pp. 144

${ }_{6}^{5}$ Политичка Енииклопедија, (1975),Савремена администрација, Београд, стр.105

6 TreccaniEnciclopedia, Istituto della Enciclopedia Italiana, https://www.treccani.it/enciclopedia/ censural, Accessed 20.05.2021. 
конторлирање или ограничување на сопствените мисли и размислувања или пак ограничување поставено од страна на медиумот заради различни причини, кои најчесто се поврзани со страв од лоши последици. Автоцензурата се поврзува и со ограничување на зборовите и сликите кои се употребуваат, односно на нивен слектиран избор. Ваквата внимателност претставува еден вид на автоцензура, бидејќ н новинарот или уредништвото на медиумот одлучуваат каква информативна содржина да понудат на јавноста. Бидејќи ваквите избори ги вршат самите новинари и уредници, без надворешни притисоци, автоцензурата обично не преставува кршење на слободата на говорот и слобода на печатот. Автоцензурата треба само да биде добро избалансирана помеѓу правото на граѓаните на вистинито информирање и остварувањето на слободата на печат. Во новинарската професија и медиумските кругови повеќе се дава предност на автоцензурата (доброволната) во однос на присилната или надворешната цензура, бидејќи новинарот, поагајќи од сопствените моралните принципи и начела сам одлучува дали и како за нешто ќе информира, водејќи сметка за балансирање на почитувањето на правото на граѓаните на информирање и почитувањето на другите правата и слободите на граѓаните.

Во продолжение е даден краток осврт на правната заштита на правото на слободата на изразување со посебен осврт на изразувањето преку медиумите со цел да се види кои се правнита алактки кои го штитат ова право.

\section{2 Правото на изразување во меѓународните и национални акти}

Првиот правен акт кој содржи одредби за слободата на изразување е Универзалната декларација за човекови права во чиј член 19 се одредува:,секој има право на слобода на мислење и изразување. Ова право ја вклучува и слободата да се застапува одредено мислење без никакво вмешување и да се бараат, да се примаат и да се даваат информации и идеи преку медиумите и без оглед на границите, ${ }^{7}$. Во Меѓународниот пакт за основни граѓански и политички права пак се одредува дека: „секој има право на слобода на изразување и дека ова право подразбира слобода да се бараат, примаат и шират известувања и идеи од секој вид, без оглед на границите, било усно, писмено, по пат на печат или во уметничка форма, или со кое било друго средство по свој избор. Неговото остварување секако дека повлекува посебни обврски и одговорности и истото може да биде подложено на одредени ограничувања кои сепак мора дабидат изречно утвредни со закон и кои се нужни: а) за почитување на правата и угледот на другите лица; б) за заштита на националната безбедност, или јавниот поредок, или јавното здравјеили морал,,. . Според член 1 од Европската

\footnotetext{
${ }^{7}$ Чл.19, Универзална декларација за човекови права.Unitednations, https://www.un.org/en/about-us/ universal-declaration-of-human-rights, Accessed 25.05.2021.

${ }^{8}$ Чл.19, Меѓународниот пакт за основни граѓански и политички права, Unitednationshumanrights, officeofthehighcommissioner, $\quad$ https://www.ohchr.org/EN/ProfessionalInterest/Pages/CCPR.aspx, Accessed 25.05.2021.
} 
Конвенција за заштита на човековите права ${ }^{9}$ „секој човек има право на слобода на мислите, совеста и верата. Слободата на изразување на својата вера или убедувања може да биде предмет на оние ограничувања што се предвидени со закон или претставуваат мерки во интерес на јаванта безбедност, поредок, здравје и моралот или заштита на правата и слободите на другите, неопходни во едно општество,. Во член 10 пак кој е насловен Слобода на изразување се одредува: „секој човек има право на слобода на изразување, на мислење, на примање и пренесување на информации и идеи, без мешање на јавната власт и без оглед на границите,.. Овој член не ги спречува државите, на претпријатијата за радио, филм и телевизија да им наметнуваат режим на дозволи за работа. Оттука може да се каже дека слободата на изразувањето опфаќа три компоненти: слободата на мислењето, слободата на примањето и слободата на пренесувањето информации. Ова особено се однесува на новинарските права и слободи на размислување, барање, добивање информации за прашања од јавен интерес, право на извори и на анонимни извори, право да се објави и да се коментира во текстовите за прашања од јавната проблематика, право на заштита на материјалите со кои располага, но пред сѐ на сопствената безбедност и живот - ако се знае дека новинарството е трета по ред најризична професија во светот. Со цел да се одговори на модерното и динамично комуницирање одредбите од конвенцијата не ги ограничува државите да воведат свој правен ред и режим што се однесува до давањето дозволи за работа на електронските медиуми, но ги одредува околностите под кои државата може да се меша, и тоа легитимно, во остварувањето на слободата на изразување. Друга правна рамка во која е вклучено правото на слобода на изразување е Повелбата за темелните права на ЕУ ${ }^{10}$, во чиј член 11 се одредува дека секој има право на слободен израз вклучувајќи ги тука: слободата на сопственомислење и примање и давање информации и идеи, без вмешаност од јавно тело и без оглед на границите. Покрај ова се одредува дека се почитува слободата и плурализмот на медиумите. Конкретно во однос на регулирањето на изразувањето преку медиумите, односно работата на медиумите во Европската Унија се донесени и низа директиви меѓу кои Директивата на Европскиот парламент и Советот за аудиовизулени и медиумски услуги, потоа усвоена е финасиски политики за развој на секторот за аудиовизулени услуги, кои се дел од програмата за Креативна Европа, како и Упатство за човекови права за слобода на изразување по електроснки и редовен пат.

Во однос на националната правна регулатива, во членот 16 од македонскиот Уставот се предвидени одредбите од членот 10 на Европската

\footnotetext{
${ }_{9}^{9}$ Чл.1, Европската Конвенција за заштита на човековите права, CouncilofEurope, https://www.coe. int/en/web/conventions/full-list/-/conventions/treaty/005, Accessed 25.05.2021.

${ }^{10}$ Чл.11, Повелбата за темелните права на ЕУ, EuropeanParliament, https://www.europarl.europa.eu/ charter/default en.htm, Accessed 25.05.2021.
} 
Конвенција за заштита на човековите, односно се гарантирани слободата на изразување и информирање, а цензурата, за разлика од конвенцијата во која не се наведува, македонскиот устав ја забранува. Од законската регулатива која го третира прашањето за слобода на изразување може да се напоменат: Законот за медиуми, Законот за аудио и аудиовизулени медиумски услуги, Законот за слободен пристап до информации од јавен карактер, како и Законот за граѓанска одговорност за клевета и навреда.

Замјќ́ ја во предвид целокупната регулатива која е усвоена како на меѓународно ниво така и поединечно во секоја држава, на глобално ниво постојат механизми, односно организации кои вршат мониторинг во однос на почитувањето и имплементирањето на овие закони, а со цел подобрување на слободата на медиумите и слободата на изразување во светот. Меѓу овие може да се напоменат: Меѓународен институт за печат со седиште во Цирих, Репортери без граници, FreedomHouse, IFEX - International Freedom of Expression Exchange, Меѓународен институт за прес, Меѓународна федерација на новинари и други. Во извештајот на Репортери без граници од 2021 година ${ }^{11}$, според World Press Freedom Index за 2021 година, на прво место на ранг листата е Норвешка, по која доаѓаат другите скандинавски држави, како и Коста Рика, Јамајка, Холандија, додека Македонија се наоѓа на 90-тото место, односно за две места погоре од минатагодишното рангирање. Во однос на истражувањата кои ги прави Freedom House ${ }^{12}$, бодувањето за 2021 во однос на тоа „дали има слободни и независни медиуми,, изнесува 3 од вкупно 4, а во извештајот е наведено дека медиумите се длабоко поларизирани по политичка линија, додека приватните медиуми зависат како од политичките, така и од деловните интереси, и истите влијаат на самите содржини. Покрај ова се наведува дека сепак постои широк критички и независен осврт кој може да се најде на интерент. Како и да е во извештајот се наведува дека новинарите се предмет на политички притисок и вознемирување, а не се изоставени и физичките напади.

Во продолжение се изнесени резултатите од истражувањето кое беше спроведено во месец мај 2021 година, а се однесува на перцепцијата на медиумските работници за степенот на слободата на изразување. Во ова истражување се опфатени медиумските работници од Западниот плански регион во Македонија.

\footnotetext{
${ }^{11}$ Reporters without borders, https://rsf.org/en, Accessed 20.05.2021.

12 Freedom House, https://freedomhouse.org/country/north-macedonia/freedom-world/2021, Accessed 20.05.2021.
} 
2. Истражување на тема: «Каква е перцепцијата на медиумските работници за степенот на слободата на изразување во Западниот плански регион на Република С. Македонија?»

\section{1. Цели, предмет и временска рамка на истражувањето}

Истражувањето на тема:,перцепцијата на медиумските работници за степенот на слободата на изразување во Западниот плански регион на Република С. Македонија, има истовремено општа и конкретна цел: прво да ја даде генералната слика за перцепцијата на новинарите и медиумските работници во овој дел од земјата за слободата на изразување, но и да покаже зошто е тоа така. Односно, конкретно да се идентификуваат факторите што влијаат врз слободата на изразување. Оттука основно прашање во спроведеното истражување е,каква е перцепцијата на медиумските работници за степенот на слободата на изразување во Западниот плански регион на Република С. Македонија?,. Истражувањето ги опфати сите медиумски работници (новинари, технички персонал) од печатени и електронски (радија, телевизии и интернет портали) медиуми во Тетово, Гостивар, Битола, Струга, Кичево, Охрид и Дебар. Централниот извор на контакти со испитаниците беше Здружението на новинари на Македонија, каде постои регистар на медиумски работници од сите типови медиуми во западниот регион. Истражувањето се спроведе во периодот помеѓу 26 мај и 5 јуни 2021 година, а на анкетниот прашалник одговорија 70\% од вкупниот број на медиумски работници.

\section{2.Методологија на истражувањето}

За потребите ова истражување беше креирана електронска анкета ${ }^{13}$ која беше испратена електронски до сите испитаници. За поголема ефикасност на спроведувањето на анкетата, испитаниците беа контактирани и телефонски од страна на студентите по новинарство на Универзитетот „Гоце Делчев,,- Штип. Важно е да се нагласи дека анонимноста на анкетата овозможи поголем интерес од испитаниците да ги одговорат поставените прашања. Во сумирањето на резултатите од истражувањето беа користени истражувачките методи на анализа, синтеза, дескриптивниот метод, статистичкиот метод и др. Се водеше грижа во структурата на примерокот да биде подеднакво застапена половата, возрасната и етничката категорија.

\section{3. Хипотетска рамка на истражувањето}

Во истражувањето се поаѓа од општата претпоставка дека врз перцепцијата на медиумските работници на слободата на медиумите влијаат повеќе фактори кои меѓусебно се испреплетуваат. Оттука, во истражување поаѓаме од

\footnotetext{
${ }_{13}$ Наслов на анкетата: Анкетен прашалник за потребите на проектот: Перцепција на слободатана изразување на медиумските работници во Западен регион на Република С. Македонија, достапна на: https://docs.google.com/forms/d/1Ohh-vhJqdU2jTmn0utSP-M580zM8VLAk1Y1xYsim0Tc/prefill
} 
претпоставката дека врз перцепцијата на медиумските работници на слободата на медиумите влијаат социо-економската положба на медиумските работници. Несомнено, мошне важен фактор којшто влијае на перцепцијата на медиумските работници врз слободата на изразување, секако е и образовниот статус на самите новинари. Важен фактор којшто има соодветно влијае врз перцепцијата на медиумските работници за слободата на изразување е правната регулатива со која се регулираат општествените односи во медиумската сфера во Република С. Македонија. Самата анализа на одговорите за правната регулатива ќе утврди дали и колку таа влијае врз слободата на изразување. Исто така, во нашето истражување ќе утврдиме дали и колку влијае ефикасноста на институциите кои имаат надлежност во работата на медиумите, како и политиките што тие ги креираат и имплементираат во оваа сфера. Врз слободата на изразување на медиумските работници во Западниот регион на РСМ влијае и работноправниот статус на вработените во медиумите, како и уредувачката политика, сопствениците на медиумите, бизнис интересите (на локално, регионално и национално ниво), политиката на сите нивоа, професионалното организирање и здружување, односно саморегулаторните тела во државата, функционирањето на институциите кои имаат надлежност во оваа сфера и меѓународната контрола.

\section{4. Резултати од истражувањето}

Општата оценка на истражувањето е дека слобода на изразувањето на медиумските работници е „добра,, односно добиената оценка е 3 , почнувајќи од 1 - како нула слобода на изразување, до 5 - како целосна слобода на изразување. Анкетираните одговорија на 25 прашања, со цел темелно да се даде сликата за клучното прашање: «каква е перцепцијата на медиумските работници за степенот на слободата на изразување во Западниот плански регион на Република С. Македонија?». Во продолжение се изнесени деалите за анекетата.

Половата застапеност на учесниците во анекетата во проценти изнесува $54,5 \%$ мажи и $45,5 \%$ жени. $63,6 \%$ од испитаниците се на возраст од 18 до 35 години, $27,3 \%$ се на возраст од 35 до 55 години, а останатите $9,1 \%$ се постари од 56 години. Најголем дел од испитаниците или $54,5 \%$ работат во национални телевизии, најчесто како дописници, $22,7 \%$ во интернет портали, а останатите $18,2 \%$ се изјасниле под графата „друго“.

Во однос на застапеноста на новинарите, $59,1 \%$ од испитаниците се новинари, додека $36,4 \%$ се изјасниле со позицијата новинар - уредник, додека останатите одговориле под категоријата „други“. Од испитаниците 45,5\% одговориле дека во нивните медиуми се вработени над 60 луѓe, 31,8\% дека работат во медиумски куќи со до 20 вработени, а $22,7 \%$ во медиуми до 60 вработени. Вкупно $54,5 \%$ одговориле дека во медиумите има повеќе технички персонал отколку новинари, а останатите $45,5 \%$ пак се изјасниле дека во нивните фирми има повеќе новинари отколку технички персонал. Заслужува внимание 
податокот дека половина од испитаниците одговориле дека новинарите во нивните медиуми немаат завршено новинарски студии, туку други видови на високо образование, $31,8 \%$ одговориле дека завршиле факултет за новинарство, а $18,2 \%$ се изјасниле дека запишале новинарски студии, но се уште не завршиле.

Едно од клучните прашања кое ја определува генералната оценка на перцепцијата на новинарите во западниот регион е платата, односно финансискиот надоместок на месечно ниво. Тука ситуацијата е далеку од розова, имено мнозинството се изјасниле дека работат за надоместок понизок од просечната месечна плата во државата, односно до 20000 денари (40,9\%). $18,2 \%$ земаат надоместок од 20000 до 30000 денари, 31,8\% земаат од 30000 до 40000 денари секој месец, а останатите 9,1\% примаат над 40000 денари секој месец. Но, ако стабилното вработување влијае врз перцепцијата, тогаш тука сликата е позитивна, односно 63,6\% од анкетираните се вработени на неопределено време, 22,7\% на определено, а останатите 13,6\% одговориле дека се хонорарно ангажирани.

На двата прикази во продолжение се гледа дека мнозинството од оние кои одговориле или $68,2 \%$ не се доволно платени за тоа што го работат, а останатите $31,8 \%$ одговориле потврдно. Мнозинството $(59,1 \%)$ од медиумите се финансираат од реклами и други дотации, 22,7\% исклучиво од други дотации, а $18,2 \%$ исклучиво од реклами.

Се чувствувате ли доволно платени за тоа што го работите:

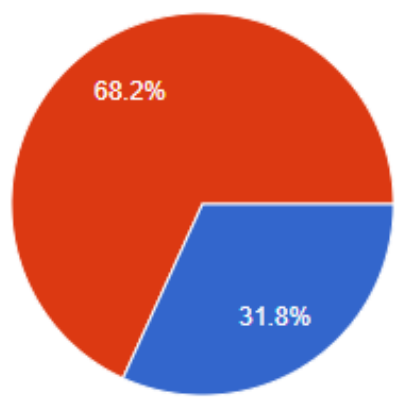




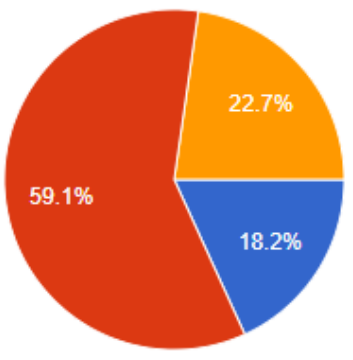

исклучиво од реклами

од реклами и од други дотации

исклучиво од други дотации

Половина од испитаниците се изјасниле дека во темите за кои известуваат доминираат сите прашања подеднакво и регионални и локални и национални.

На прашањето „дали се чувствуваат слободни да пишуваат и објавуваат за теми што го засегаат местото каде живеат и работат?“ $45,5 \%$ одговориле дека целосно се чувствуваат слободни, $40,9 \%$ дека во поголемиот дел од темите се чуствуваат слободни, а 13,6\% одговориле дека не можат да објават ништо без одобрение од уредник.

Се чувствувате ли слободни да се изразите и да објавите било каква тема што го засега местото каде живеете и работите:

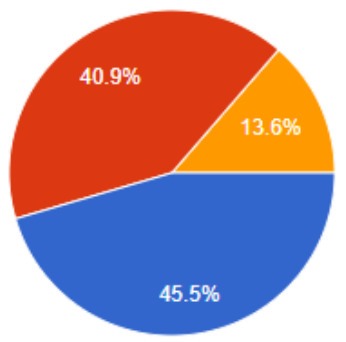

да, секогаш

во поголем дел од темите да без одобрение од уредник/ директор не смеам да објавам речиси ништо секогаш прво уредник/ директор одобрува

На прашањето со не повеќе од 2 реченици да опишат како ја разбираат слободата на медиумите, во мнозинството од одговори доминира зборот „слобода“ (на пример: слобода на медиумите треба секогаш да остане така; слободно мислење, слободни раце за пишување!; слободно изразување; слободата на изразување ја разбирам како можност за објавување на сите 
вести, особено на тие „пожешките“; слобода на комуникација и изразување, без мешање на други лица“). Но има и такви кои не мислат дека медиумите се слободни (на пример: слободата е сеуште заробена). Испитаниците одговориле и порачувајќи дека новинарите не треба да чувствуваат редакциски притисок, или друг вид на притисок да известуваат за прашања од јавен интерес.

Во врска со рангирање на факторите кои влијаат врз слободата на изразувањето на новинарите од најважен па надолу, првите пет се: уредувачката политика, политиката на сите нивоа, бизнис интересите на сопственикот на медиумот, самиот сопственик, правната регулатива во оваа сфера, материјалмниот статус и функционирањето на институциите надлежни во оваа сфера. Процентите на одговорите се илустрирани во графиконот во продолжение.

Врз слободата на изразување во медиумот во кој работите влијае (селектирајте ги петте први фактори кои според вас најмногу влијаат):

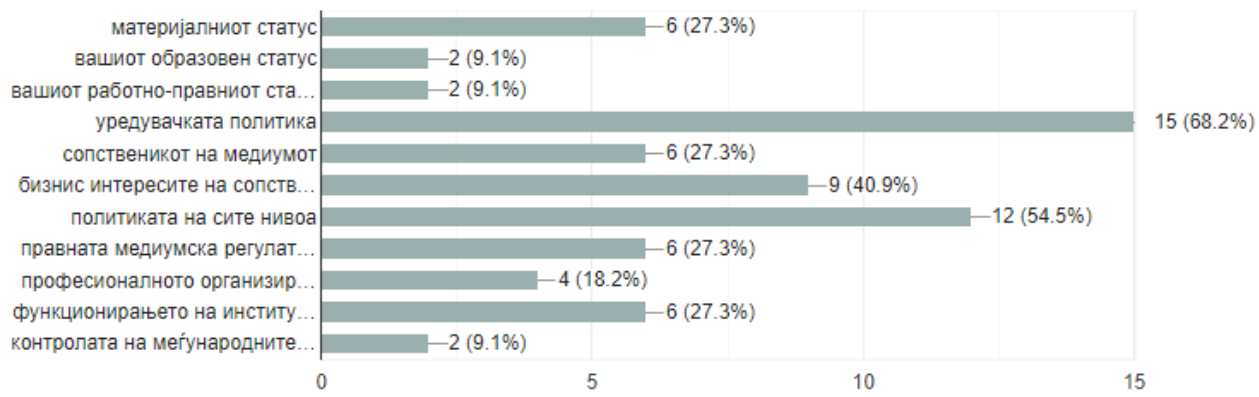

Мнозинството од испитаниците, односно 54,5\% се изјасниле дека кога би имале можност би ја смениле новинарската/медиумската професија со друга, додека 45,5\%одговориле дека не би ја напуштиле.

На прашањето „дали новинарите треба да преземат нешто и ито за да подобрат ситуащијата на прифесионално, етичко, морално ниво“, повеќе пати се повторува одговорот дека „има сериозна поделеност внатре во фелата.. новинаритетребада ја сфатат одговорноста која ја носат и да делуваат согласно неа. A потоа да си го зачуваат достоинството и да не дозволат да бидат алатка за манипулација од страна на оние кои им ја даваат платата - платени се за да го информираат народот и да ја бараат вистината, а не да задоволат нечии интереси“, како и дека „треба организирано да ја средат политиката на саморегулирање преку здруженијата на новинарите, а не преку самите медиуми или портали“. Добар дел сметаат дека медиумските работници не се доволно гласни, како и дека е потребна поголема активност на синдикатот 
и здруженијата. Се повторуваат и одговорите дека се неопходни реформи во Здружението на новинари (ЗНМ), но и поголеми плати, истражувачко новинарство и посилни заложби за борба против заканите и притисоците. Со оценка 3, односно добра, испитаниците го оцениле работењето на ЗНМ и неговите заложби за медиумските работници, а во Здружението и најголем дел од нив се обраќаат кога се прекршени или повредени нивните права.

Клучното прашање кое е претставено во следните две илустрации најблиску ја отсликува перцепцијата на медиумските работници за слободата на изразувањето, тоа е: „дали постои иензура во медиумите во Македонија“. Мнозинството одговорило дека има делумна цензура, а помалку се изјасниле дека цензурата е целосна. Но од кого, одговорот е во следното прашање. Имено, $31,8 \%$ одговориле дека цензурата е наметната од бизнис заедницата, $27,3 \%$ дека притисоците и цензурата доаѓаат од политичките партии, $18,2 \%$ од државните институции, а останатите дека цензурата стигнува од уредниците, од локалната власт, но мал дел велат и дека самите си прават автоцензура. Мнозинството, $72,7 \%$ одговориле дека „некогаш биле подложни на цензура или автоцензура“.

Дали постои цензура во медиумите во Република С. Македонија?
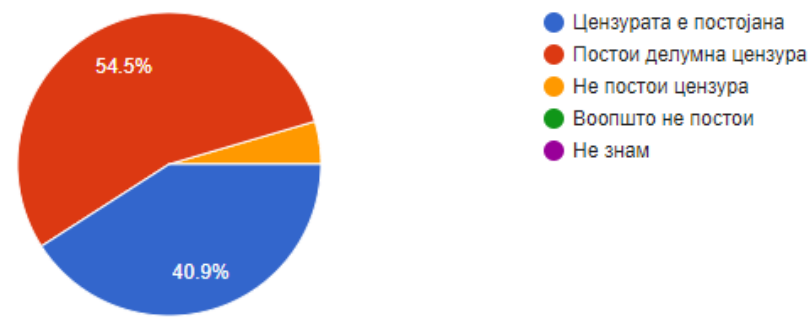

Со каков вид на цензура најчесто се соочувате?

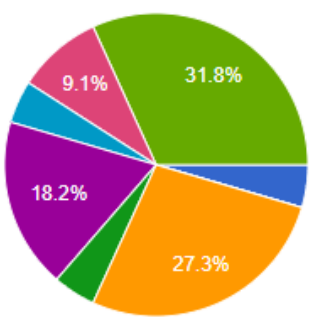

Притисоци од претпоставените (уредници)

- Притисоци од сопственикот на медиумот

Притисоци од политичките партии

- Притисоци од бизнис заедницата

- Притисоци од државните институции

Притисоци од локалната власт

Автоцензура

Друго 
Во однос на кои фактори навеќе влијаат за автоцензурирање во работењето на медиумските работници, $36,4 \%$ одговориле дека тоа е „стравот од губењето на работното место“, а следниот мнозински процент од 18,2\% одговориле дека во прашање е „немање професионален и морален интегритет кај новинарите“.

Во врска со соодветна законска регулатива што ги штити нивните права, $40,9 \%$ одговориле дека неопходна е нејзина промена, а добар дел и дека регулатива постои, но не се почитува.

На последното прашање прикажано на следната фотографија (каде оценките се движат од 1 до 5, (односно од најлошо до најдобро) „колкава е слободата на изразување на медиумите во Западна Македонија, мнозинството (54,5\%) дале средна оценка, односно 3; потоа оценка 2 и оценка 4 дале ист процент на испитаници (по $18,2 \%$ ), а со единица слободата ја оцениле $9,1 \%$ од испитаниците.

На скала од 1 до 5 оценете ја слободата на изразување во медиумите во Западна Македонија, каде 1 означува непостоење на слобода на изразување/слобода на медиуми, а 5 максимален степен на слобода на изразување/слобода на медиуми:

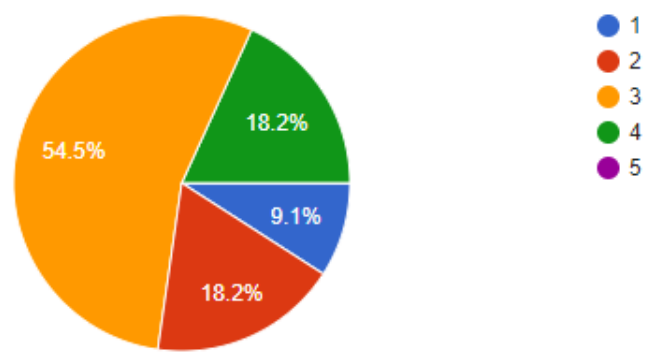

\section{Заклучок}

Една од историските искажани мисли која најдобро ја дефинира силата и моќта на слободата на медиумите е онаа на францускиот император Наполеон Бонапарта кој ќе каже: «Четири непријателски весници можат да бидат поопасни од стоилјадна војска», или «Кога би ги пуштил уздите на печатот, не би се одржал на власт ни четири месеци». Новинарите се контролните механизми за унапредување, корекција и одржување на демократските процеси и состојби во едно општество. Оттука е многу важно да се обезбеди слобода во нивното делување и креација, и во филозовска и во практична смисла на зборот. А тоа, пред се, значи професионален и финансиски интегритет, безбедни услови за 
работа, сигурност на работното место. А колку се истите реализирани покажуваат и процентите од одговорените прашања, во нашето последно истражување спроведено меѓу медиумските работници во медиумите во западниот регион на државата. Од истражувањето дојдовме до следните заклучоци: 1) Општата оценка на истражувањето е дека слобода на изразувањето на медиумските работници е «добра»; 2) Големо мнозинство од новинарите (68,2 \%) сметаат дека не се добро платени за работа што ја извршуваат; 3) Половина од испитаниците се изјасниле дека во темите за кои известуваат доминираат сите прашања подеднакво и регионални и локални и национални; 4) Безмалку половина, 45,5 $\%$ се чувствуваат целосно слободни да пишуваат и објавуваат за теми што го засегаат местото каде живеат и работат, $40,9 \%$ за поголемиот дел од темите се чуствуваат слободни, а 13,6\% одговориле дека не можат да објават ништо без одобрение од уредник; 5) Во врска со рангирање на факторите кои влијаат врз слободата на изразувањето на новинарите од најважен до помалку важен првите 5 се: уредувачката политика, политиката на сите нивоа, бизнис интересите на сопственикот на медиумот, самиот сопственик, правната регулатива во оваа сфера, материјалмниот статус и функционирањето на институциите надлежни во оваа сфера; 6) Мнозинството од испитаниците (54,5\%) се изјасниле дека кога би имале можност би ја смениле новинарската/медиумската професија со друга, додека $45,5 \%$ не би ги напуштиле медиумите; 7) Мнозинството одговориле дека се неопходни реформи во Здружението на новинари (ЗНМ), но и поголеми плати, истражувачко новинарство и посилни заложби за борба против заканите и притисоците. Сепак со оценка 3 , односно добра, испитаниците го оцениле работењето на ЗНМ и неговите заложби за медиумските работници; 8) Мнозинството одговорило дека има делумна цензура, а помалку се изјасниле дека цензурата е целосна. Во однос на изворот на цензурата, 31,8 \% се изјасниле дека доаѓа од бизнис заедницата, 27,3\% од политичките партии, а 18,2 \% рекле дека цензурата доаѓа од уредниците, локалната власт или самите се цензурираат. 9) Околу 40 проценти од испитаниците се изјасниле дека е неопходна ревизија на правната регулатива која ги штити правата на новинарите во Република С. Македонија; 10) Мнозинството од испитаниците (54,5\%) дале средна оценка, за слободата на изразување во државата, односно оценка три (3).

\section{Биографија}

1. Анкетен прашалник за потребите на проектот: Периепиија на слободатана изразување на медиумските работници во Западен регион на Република C. Македонија, достапна на: https://docs.google.com/forms/d/1OhhvhJqdU2jTmn0utSP-M58ozM8VLAk1Y1xYsim0Tc/prefill;

2. руевски,Т.(2007),Историјанановинарството.ПравенфакултетиНИП«Студентскизбор», Скопје; 
3. Груевски, Г., (2007), Историја на новинарството,Правен факултет и НИП «Студентски збор». Скопје;

4. Европската Конвенција за заштита на човековите права, CouncilofEurope, https://www.coe.int/en/web/conventions/full-list///conventions/treaty/005;

5. Freedom House, https://freedomhouse.org/country/north-macedonia/freedomworld/2021;

6. Мајхошев, Андон (2015), Новинарска етика (авторизирани предавања), УГД, Штип;

7. Меѓународниот пакт за основни граѓански и политички права, Unitednationshumanrights, officeofthehighcommissioner, https://www.ohchr. org/EN/ProfessionalInterest/Pages/CCPR.aspx;

8. Повелбата за темелните права на ЕУ, EuropeanParliament, https://www. europarl.europa.eu/charter/default en.htm;

9. Политичка Енциклопедија, (1975), Савремена администрација, Београд.

10. Reporters without borders, https://rsf.org/en;

11. Zaket, D. (2007), Novinarskaetika - moralnaodgovornostumedijima, Sluzbenglasnik;

12. TreccaniEnciclopedia, Istituto della Enciclopedia Italiana, https://www.treccani.it/enciclopedia/censura/;

13. Универзална декларација за човекови права.Unitednations, https://www. un.org/en/about-us/universal-declaration-of-human-rights;

14. Устав на Република Македонија, https://www.sobranie.mk/content/Odluki\%20USTAV/UstavSRSM.pdf;

15. Шкариќ С., Силјановска-Давкова Г., (2009), Уставно право Култура, Скопје; 